\title{
PENINGKATAN KETERAMPILAN BERPIKIR KRITIS MELALUI PEMBELAJARAN METODE PENEMUAN TERBIMBING DALAM UPAYA REMEDIASI MISKONSEPSI MATERI LISTRIK DINAMIS
}

\author{
M. Anas Thohir ${ }^{1)}$ \\ Wasis $^{2)}$ \\ Sugimin $\mathbf{W W}^{3)}$ \\ 1) Mahasiswa Pendidikan Sains Pascasarjana Unesa \\ 2) Dosen Fisika Unesa \\ 3) Dosen Fisika ITS \\ e-mail: anasthohir@gmail.com
}

\begin{abstract}
This research is focused to remediate students's misconceptions to dynamic electrical materials. Remediation activities are performed by improving critical thinking skills through guided discovery learning method. This research through two stages, namely the stage of development of learning instrument that using the design of 4-D models Thiagarajan (1974) continued with the implementation of the 35 students on Physics Education 2011 class A at State University of Surabaya by one group pretest-posttest design. The results of data analysis showed that the devices in good category, assement of the implementation of guided discovery learning method derived from observer with good category. Implementation of guided discovery methods of learning dynamic electric materials can improve critical thinking skills of the students. Profiles initial misconceptions are found in each of the concepts before learning and decreased after remediation. The result is closely linked to increased student thinking skills. Based on data analysis, it can be concluded that learning instrument was developed to enhance the learning of critical thinking skills in an effort to remediate student's misconceptions dynamical electric material, but the result of correlation analysis between improving critical skill with remediation of misconceptions is not significant.
\end{abstract}

Key words: Remediation; misconception; critical thinking skills; guided discovery learning method

\begin{abstract}
Abstrak: Penelitian ini bertujuan untuk meremediasi miskonsepsi mahasiswa materi listrik dinamis. Kegiatan remediasi dilakukan dengan meningkatkan keterampilan berpikir kritis melalui pembelajaran metode penemuan terbimbing. Penelitian ini melalui dua tahap, yaitu tahap pengembangan perangkat mengikuti rancangan 4-D model Thiagarajan (1974) dilanjutkan dengan implementasi perangkat pada 35 mahasiswa Pendidikan Fisika 2011 kelas A di Universitas Negeri Surabaya dengan desain One Group PretestPosttest Design. Analisis yang digunakan adalah analisis deskriptis dan kuantitatif. Data hasil penelitian menunjukkan penilaian perangkat dalam kategori baik, keterlaksanaan pembelajaran metode penemuan terbimbing diperoleh dari penilaian pengamat mendapatkan nilai rata-rata keterlaksanaan 3,6 dengan katagori sangat baik. Implementasi pembelajaran metode penemuan terbimbing materi listrik dinamis dapat meningkatkan keterampilan berpikir kritis mahasiswa. Profil miskonsepsi awal ditemukan pada setiap konsep sebelum pembelajaran dan menurun setelah remediasi. Penemuan tersebut tidak terlepas dari meningkatnya keterampilan berpikir mahasiswa. Berdasakan hasil analisis data, dapat disimpulkan bahwa perangkat pembelajaran yang dikembangkan dapat meningkatkan keterampilan berpikir kritis dalam upaya remediasi miskonsepsi mahasiswa materi listrik dinamis, namun hasil analisis pengaruh peningkatan keterampilan berpikir kritis terhadap remediasi miskonsepsi tidak signifikan.
\end{abstract}

Kata-kata kunci: Remediasi, miskonsepsi, keterampilan berpikir kritis, pembelajaran metode penemuan terbimbing

\section{PENDAHULUAN}

Standar

Kompetensi Lulusan

(SKL)

sekolah/perguruan tinggi dapat disesuaikan dengan karakteristik yang diinginkan dunia kerja, seperti karaktristik lulusan Universitas Negeri Surabaya yaitu memiliki sikap dan prilaku kritis, kreatif, inovatif, mengusai ilmu pengetahuan, dan pengetahuan teori (Buku Pedoman Unesa, 2011). Untuk mewujudkan SKL yang diinginkan tentu memerlukan metode pembelajaran yang sesuai, termasuk metode pembelajaran untuk mengajarkan fisika.

Berdasarkan hasil observasi peneliti, diidentifikasi masalah pembelajaran fisika di perguruan tinggi yaitu; 1) perangkat yang dikembangkan masih mengacu pada berpikir tingkat bawah; 2) tingginya miskonsepsi dalam pelajaran fisika terutama materi listrik dinamis. Dua masalah ini seharusnya cepat dicarikan solusi, karena dua masalah ini akan menjadikan SKL yang diinginkan hanya sebatas tulisan yang sarat nilai tapi jauh dari kenyataan. Solusi dari dua masalah itu adalah mengembangakan perangkat pembelajaran yang metodenya dapat meningkatkan berpikir kritis dan meremediasi miskonsespsi mahasiswa.

Mengapa perlu dikembangkan perangkat keterampilan berpikir tingkat tinggi? Keterampilan berpikir tingkat tinggi (higher order thinking skills) bersifat non-algoritmik, bersifat kompleks, multiple solutions, nuanced judgment, multiple criteria, melibatkan self regulation, imposing meaning, menemukan struktur dalam bentuk tidak beraturan, dan 
membutuhkan banyak usaha (Arends, 2008). Beberapa kriteria tersebut di atas sejalan dengan keterampilan berpikir kritis. Ennis, R. H. (1996) menyatakan Critical Thinking is concerned with the judging of arguments (in the logical sense of the word argument). Jadi, dengan mengembangkan keterampilan berpikir tingkat tinggi berarti mewujudkan SKL yang sesuai dengan karakteristik dunia kerja.

Diantara motode pembelajaran yang memberikan kesempatan kepada (maha)siswa membentuk pengalamanya sendiri dan dapat meningkatkan keterampilan berpikir kritis adalah metode penemuan terbimbing (discovery learning). Pembelajaran penemuan terbimbing (guided discovery learning) adalah bagian dari pembelajaran penemuan (discovery). Sedangkan metode pembelajaran penemuan (discovery) pada hakikatnya sama dengan pendekatan inkuiri (inquiry approach), karena penemuan merupakan kelanjutan tahap inkuiri (Carin, 1993). Dari beberapa teori discovery learning, yang menjadi dasar pembelajaran penemuan terbimbing adalah kontruktivis. Pembelajaran penemuan terbimbing secara filosofis yang diformatkan dalam empat tahap, yaitu; 1) menerima invitasi untuk belajar, 2) mencari, menemukan, dan menciptakan, 3) mengusulkan penjelasan dan penyelesaian, dan 4) mengambil langkah terhadap apa yang dipelajari. Keempat tahap ini didasarkan bagaimana siswa mengkonstruksi beberapa konsep (Carin, 1993). Selain meningkatkan keterampilan berpikir kritis, mahasiswa seharusnya mempunyai konsep yang sesuai dengan ilmuan. Berg (1991) mendefinisikan miskonsepsi sebagai pertentangan atau ketidak cocokan konsep yang dipahami seseorang dengan konsep yang dipakai oleh para pakar ilmu yang bersangkutan.

Miskonsepsi terjadi pada semua tingkatan sekolah, tidak hanya pada siswa sekolah dasar tetapi juga pada perguruhan tinggi. Purba (2008), menyatakan bahwa mahasiswa telah mengalami miskonsepsi pada materi listrik dinamis sebanyak $49,47 \%$, dan 2) Saputra (2011), melakukan penelitian kepada siswa kelas X SMAN 3 Surakarta berjumlah 328 siswa dan seluruh siswa kelas X SMAN 5 Surakarta yang berjumlah 243 siswa, hasilnya persentase miskonsepsi siswa tiap konsep lebih dari $30 \%$. Sehingga perlu adanya remediasi miskonsepsi mereka.

Pada proses pengkontruksian, salah satu syarat yang harus dimiliki (maha)siswa adalah memiliki kemampuan membandingkan, mengambil keputusan mengenai persamaan atau perbedaan (Suparno, 1997). Kemampuan membandingkan, mengambil keputusan mengenai persamaan atau perbedaan merupakan ciri-ciri keterampilan berpikir berpikir kritis Schafesman (2006). Oleh karena itu, Zero, D., (2011) menyatakan bahwa keterampilan berpikir kritis dapat digunakan untuk mengevaluasi informasi baru atau situasi-situasi atau membenarkan konsep yang awalnya miskonsepsi.

Berdasarkan uraian di atas, timbullah pertanyaan, (1) apakah dengan pembelajaran metode penemuan terbimbing dapat meningkatkan keterampilan berpikir kritis? (2) Apakah miskonsepsi awal dan setelah pembelajaran metode penemuan terbimbing dapat menurun? (3) apakah pengaruh penurunan miskonsepsi disebabkan peningkatan keterampilan berpikir kritis?

\section{METODE PENELITIAN}

Penelitian ini diawali dengan pengembagan perangkat dengan menggunakan pengembangan 4-D. Model ini terdiri dari 4 tahap, yaitu: pendefinisian (define), perancang (design), pengembangan (develop), dan penyebaran (disseminate). Hanya saja pada penelitian ini terbatas sampai tahap pengembangan (develop).

Kemudian perangkat yang telah dikembangkan diterapkan di Kelas A, Pendidikan Fisika Unesa dengan memakai One-Group Pretestt - Posttest Design. Sebelum dilakukan penerapan dengan perangkat yang telah dikembangkan, tes diagnostik miskonsepsi awal diberikan, dan juga dilakukan pretes keterampilan berpikir kritis. Setelah itu dilakukan pembelajaran dengan metode penemuan terbimbing. Selanjutnya, dilakukan tes diagnostik miskonsepsi akhir dan postes keterampilan berpikir kritis. Berdasarkan tes diagnostik dan pretes-postes, dilakukan analisis. Untuk tes diagnostik menggunakan analisis CRI yang telah dikembangkan Hasan, et.al. (1999), sedangkan data hasil pretes-postes keterampilan berpikir kritis dilakukan analisis N-Gain. Gain skor ternormalisasi menunjukkan tingkat efektivitas perlakuan daripada perolehan skor atau posttest. N- Gain dirumuskan oleh Hake (1999:1) sebagai berikut:

Keterangan:

$$
\%<\mathrm{g}>=(\%<\mathrm{Sf}-\mathrm{Si}>) /(100-\%<\mathrm{Si}>)
$$

$\langle$ g $\rangle$ = indeks gain (n-gain)

$\langle\mathrm{Si}\rangle=$ perolehan skor sebelum perlakuan (pretest)

$\langle\mathrm{Sf}\rangle=$ perolehan skor setelah perlakuan (posttest)

Berdasarkan hasil analisis n-gain, diperoleh kelompok yang mengalami efektifitas pembelajaran "gain-tinggi" (peningkatan keterampilan berpikir kritis tinggi), jika $\langle\mathrm{g}\rangle \geq 0,7$; pembelajaran dengan "gainsedang" (peningkatan keterampilan berpikir kritis sedang), jika 0,7 $\rangle\langle\mathrm{g}\rangle \geq 0,3$; dan pembelajaran dengan "gain-rendah", (peningkatan keterampilan berpikir kritis rendah) jika $\langle\mathrm{g}\rangle\langle 0,3$. Dari kelompok inilah dapat ditentukan nilai rata-rata mahasiswa yang mengalami miskonsepsi. Jika nilai rata-rata miskonsepsi kelompok tinggi > rata-rata miskonsepsi kelompok sedang > ratarata miskonsepsi kelompok rendah, maka peningkatan 
berpikir kritis dapat meremediasi miskonsepsi. Jika tidak maka peningkatan berpikir kritis tidak dapat meremediasi miskonsepsi.

\section{HASIL PENELITIAN DAN PEMBAHASAN}

\section{A. Hasil Penelitian}

\section{Pengembangan perangkat}

Hasil validasi pengembangan perangkat secara singkat disajikan dalam tabel berikut:

Tabel 1. Hasil Pengembangan Perangkat

\begin{tabular}{|l|c|c|}
\hline No & Peangkat & Kategori \\
\hline 1 & RPP & Sangat baik \\
\hline 2 & Buku Ajar Mahasiswa & Baik \\
\hline 3 & Lembar Kegiatan mahasiswa & Sangat baik \\
\hline
\end{tabular}

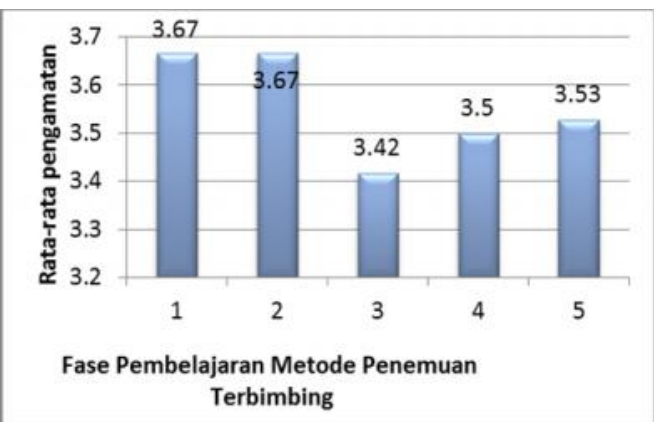

Gambar 1. Hasil pengamatan keterlaksanaan pembelajaran metode penemuan terbimbing

\section{Penerapan Perangkat Pembelajaran}

Hasil keterlaksanaan pembelajaran metode penemuan terbimbing ditunjukkan pada Gambar 1 . Keterangan gambar 1: Fase 1: Mengorientasi mahasiswa pada masalah, Fase 2: Mengorganisasikan mahasiswa untuk belajar, Fase 3: Membimbing mahasiswa dalam penyelidikan, Fase 4: Mempresentasikan hasil penyelidikan, Fase 5:Menganalisis dan mengevaluasi proses pemecahan masalah.

Hasil analisis N-Gain tiap indikator keterampilan berpikir kritis dapat disajikan pada Gambar 2 berikut:

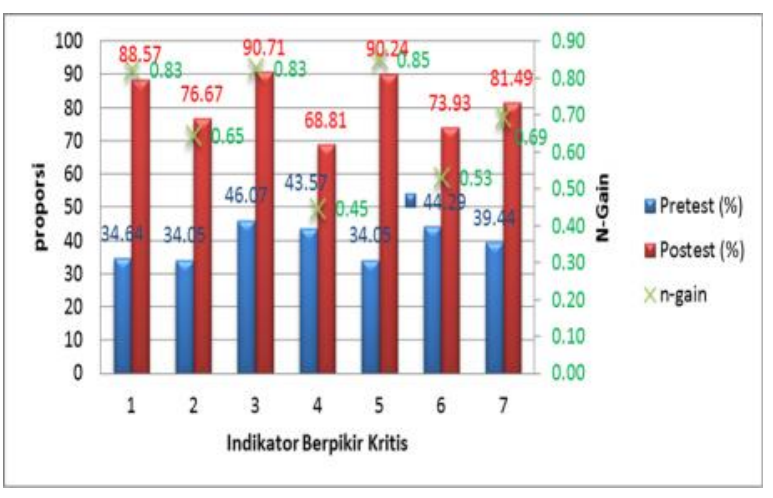

Gambar 2. Hasil analisis proporsi pretes-postes, serta ngain keterampilan berpikir kritis

Keterangan: (1) Mengenal masalah, (2) Memberikan argument, (3) Memberikan asumsi, (4) Menguji hipotesis dengan situasi-situasi (situation), (4) Menyimpulkan untuk memperjelas solusi masalah (clarity), (5) Evaluasi (overview)

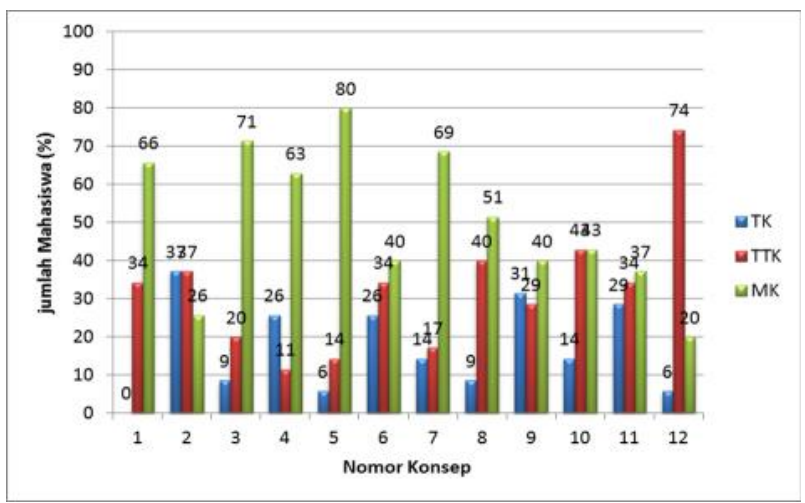

Gambar 3. Persentase Mahasiswa yang Miskonsepsi (MK), Tahu Konsep (TK), dan Tidak Tahu Konsep (TTK) Sebelum Pembelajaran Metode Penemuan Terbimbing

Keterangan Gambar 3, Gambar 4, Gambar 5, dan Gambar 6: (1) Kecepatan drift, (2) Hukum Ohm pada bahan penghantar, (3) Tegangan sumber yang dirangkai seri dan pararel, (4) Model konsumsi arus, (5) Rangkaian seri dan pararel pengaruhnya terhadap daya listrik, (6) Energi pada baterai, (7) Tipologi rangkaian listrik, (8) Daya listrik pada rangkaian campuran, (9) Arus pada suatu rangkaian, (10) Beda potensial antara dua titik, (11) Penggunaan alat ukur listrik (Ampermeter dan Voltmeter) pada rangkaian, (12) Aturan Kirchoff

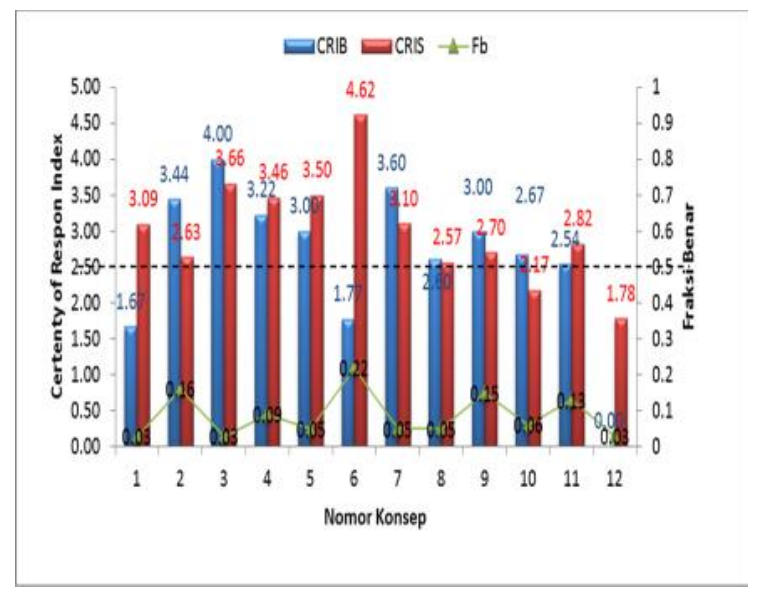

Gambar 4. Rata-rata nilai CRIB, CRIS, dan Fb tiap Konsep Sebelum Pembelajaran Metode Penemuan Terbimbing 


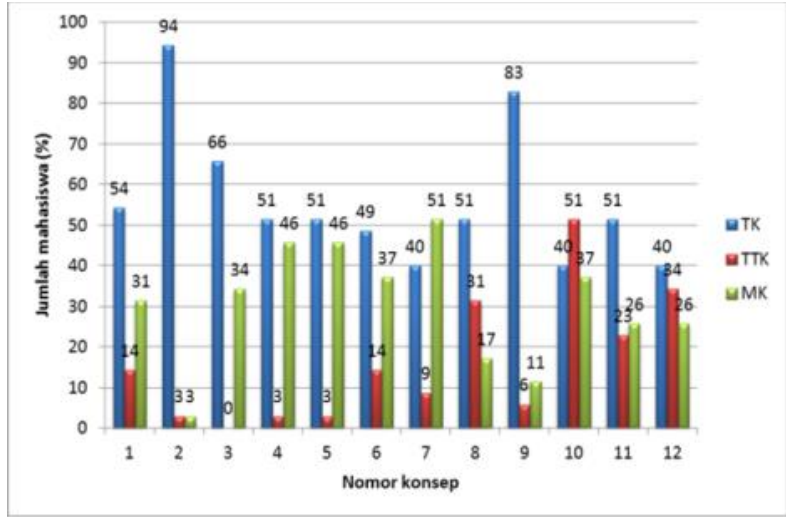

Gambar 5. Persentase Mahasiswa yang Miskonsepsi (MK), Tahu Konsep (TK), dan Tidak Tahu Konsep (TTK) Setelah Pembelajaran Metode Penemuan Terbimbing

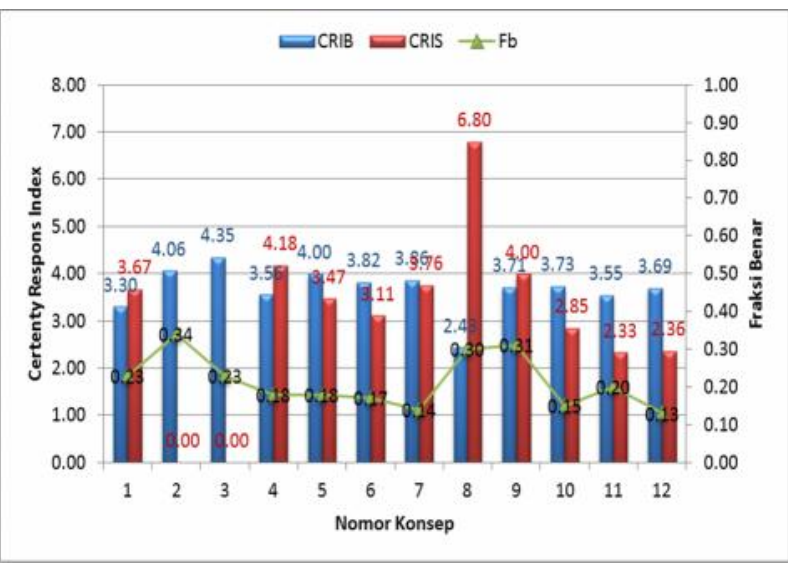

Gambar 6. Rata-rata nilai CRIB, CRIS, dan $\mathrm{Fb}$ tiap Konsep Setelah Pembelajaran Metode Penemuan Terbimbing

Tabel 2. Hasil Analisis Korelasi Peningkatan Keterampilan Berpikir Kritis (BK) dan Hasil Remidiasi Miskonsepsi (MK) Materi Listrik Dinamis

\begin{tabular}{|c|c|c|c|c|}
\hline & & & $\begin{array}{c}n- \\
\text { gainBK }\end{array}$ & $\begin{array}{c}\mathrm{n}- \\
\text { gainMK }\end{array}$ \\
\hline \multirow[t]{6}{*}{$\begin{array}{l}\text { Spearm } \\
\text { an's rho }\end{array}$} & \multirow[t]{3}{*}{$\begin{array}{l}\text { n_gai } \\
\text { nBK }\end{array}$} & $\begin{array}{l}\text { Correlati } \\
\text { on } \\
\text { Coefficie } \\
\text { nt }\end{array}$ & 1.000 & -.340 \\
\hline & & $\begin{array}{l}\text { Sig. (2- } \\
\text { tailed) }\end{array}$ & . & .077 \\
\hline & & $\mathrm{N}$ & 28 & 28 \\
\hline & \multirow[t]{3}{*}{$\begin{array}{l}\text { n_gai } \\
\text { nMK }\end{array}$} & $\begin{array}{l}\text { Correlati } \\
\text { on } \\
\text { Coefficie } \\
\text { nt }\end{array}$ & -.340 & 1.000 \\
\hline & & $\begin{array}{l}\text { Sig. (2- } \\
\text { tailed) }\end{array}$ & .077 & \\
\hline & & $\mathrm{N}$ & 28 & 28 \\
\hline
\end{tabular}

Tabel 4.21 Spearman's rho memaparkan nilai koefisien korelasi antara peningkatan keterampilan berpikir kritis dengan penurunan miskonsepsi sebesar -0,340. Nilai Sig $(0,077)>(0,05)$. Hal ini memberikan arti hubungan peningkatan keterampilan berpikir kritis dengan penurunan miskonsepsi tidak signifikan.

\section{B. Pembahasan \\ Penerapan Perangkat Pembelajaran}

Keterlaksanaan kegiatan inti lebih banyak mahasiswa bekerja secara mandiri dalam kelompok kecil dari pada bimbingan dosen. Sebagaimana yang di dinyatakan Woolfolk (2009) dan Carin (1993) bahwa pembelajaran penemuan terbimbing adalah metode yang memadukan antara pembelajaran yang berpusat pada guru/dosen (teacher-centered) dengan pengajaran yang berpusat pada (maha)siswa (student-centered). dominansi lebih banyak pada (maha)siswa dari pada guru/dosen yang bekerja, tetapi bimbingan guru/dosen sangat penting. Keterlaksanaan kegiatan inti mendapatkan skor rata-rata 3,5 dengan katagori baik.

Pada tahap mengorganisasikan mahasiswa dalam kelompok belajar. Pada awalnya mahasiswa diminta untuk memikirkan rumusan masalah dari fenomena yang tertera dalam slide. Masalah ini digunakan untuk mengikat siswa pada rasa ingin tahu pada pembelajaran yang dimaksud (Duch J.B, 1995). Kemudian dosen membagi mahasiswa secara heterogen yang terdiri dari 45 mahasiswa pada tiap kelompok dengan kemampuan yang berbeda-beda, laki-laki dengan perempuan. Pada tahap berikutanya mahasiswa memikirkan solusi dari belbagai sudut pandang keilmuan. Dalam kelas yang menerapkan pembelajaran berbasis masalah, siswa bekerja dalam tim untuk memecahkan masalah dunia nyata (Major, C.H. dan Palmer, B., 2001). Pada tahap berikutnya perwakilan dari masing-masing kelompok diminta untuk mempresentasikan hasil pengamatan, temuan, dan diskusinya.

\section{Peningkatan Keterampilan Berpikir Kritis}

Mengenal masalah (1) pada pembelajaran metode penemuan terbimbing berada pada tahap pendahuluan. Mengenal masalah dalam Ennis (1996) dikenal sebagai focus. Kata ini sesuai dengan namanya yaitu sebelum melakukan apapun, mahasiswa harus mengenal masalah. Mengenal bukan hanya sekedar dapat merumuskan, tetapi mendefinisan berbagai vareabel dalam masalah tersebut. Berdasarkan data pada Gambar 2 pada indikator mengenal masalah sebelum pembelajaran dengan pembelajaran metode penemuan terbimbing proporsi skor tes yang didapat adalah $35 \%$, kemudian setelah pembelajaran mendapatkan proporsi skor tes $89 \%$, jika dinormalisasikan n-gain mendapatkan 0,83 dengan kreteria pembelajaran benilai n-gain tinggi. Hal ini menunjukkan bahwa peningkatan indikator keterampilan berpikir kritis mengenal masalah dipengaruhi oleh fase 
pembelajaran metode penemuan terbimbing yang dimulai pengajuan pertanyaan atau masalah (Carin, 1993).

Indikator (2) memberikan argumen, sebelum pembelajaran dengan pembelajaran metode penemuan terbimbing diimplementasikan mendapatkan skor proporsi $34 \%$. Setelah dilakukan implementasi pembelajaran metode penemuan terbimbing skor yang didapat meningkat menjadi $77 \%$, nilai normalisasi ngain mendapatkan 0,69 dengan kategori kreteria pembelajaran n-gain sedang. Peningkatan skor indikator memberikan argumen tidak lepas dari peningkatan keterampilan memberikan alasan-alasan yang logis pada suatu masalah pada pembelajaran dengam pembelajaran metode penemuan terbimbing. Menurut Joe (1968) memberikan argumen-argumen yang logis merupakan bagian dari keterampilan berpikir kritis. Sedangkan menuru John Dewey dalam Fisher (2001) menyatakan bahwa keterampilan berpikir kritis adalah pertimbangan yang aktif, pertimabangan aktif menurut belbagai sudut pandang dan argumen-argumen. Ketika mahasiswa diberikan masalah mereka harus mencari solusi dengan belbagai argumen-argumen, mereka harus mempertahankan hasil solusi itu dengan argumentargumen ketika mempresentasikan dihadapan temanteman mereka.

Indikator (3) memberikan asumsi (inferensi), sebelum pembelajaran dengan pembelajaran metode penemuan terbimbing diimplementasikan skor yang didapat proporsi $46 \%$, setelah pembelajaran mendapatkan skor $91 \%$, dan nilai n-gain 0,83 dengan kategori tinggi. Schafesman (2006) mengemukakan ciriciri pemikiran kritis berusaha untuk mengantisipasi kemungkinan-kemungkinan konsekuensi dari tindakan alternatif. Sebelum mahasiswa melakukan percobaan, mereka harus mengantisipasi kemungkinan-kemungkinan sehingga mereka dapat menentukan langkah-langkah yang tepat untuk suatu percobaan tersebut. Hal ini yang memungkinkan peningkatan keterampilan berpikir kritis mereka terutama pada indikator memberikan asumsi.

Indikator (4) menguji hipotesis dengan situasisituasi (situation), sebelum diimplementasikan pembelajaran dengan pembelajaran metode penemuan terbimbing didapatkan skor proporsi $44 \%$, setelah pembelajaran mendapatkan skor $69 \%$, dan nilai n-gain 0,45 dengan kategori sedang. Meskipun mendapatkan peningkatan rendah tetapi kemampuan mahasiswa dalam menguji hipotesis termasuk tinggi, sehingga antara pretes dan postes berbeda $25 \%$. Peningkatan ini disebabkan pada fase 3 pembelajaran metode penemuan terbimbing (membantu investigasi mandiri dan kelompok) dosen mendorong mahasiswa untuk mengumpulkan informasi yang sesuai dan melaksanakan eksperimen untuk mendapatkan penjelasan serta pemecahan masalahnya.
Indikator (5) menyimpulkan untuk memperjelas solusi masalah (clarity), sebelum pembelajaran mendapatkan nilai proporsi $34 \%$, setelah pembelajaran mendapatkan skor $90 \%$, dan nilai n-gain mendapatkan nilai 0,85 dengan kategori tinggi. Indikator menyimpulkan menurut Duron (2006) termasuk dalam taksonomi Bloom, yaitu synthesis (sintesis) yang didefinisikan sebagai berpikir kritis yang fokus pada mengambil beberapa bagian untuk dibentuk menjadi suatu bentuk yang baru dan utuh seperti semula. Peningkatan $56 \%$ ini disebabkan pada fase pembelajaran metode penemuan terbimbing (menganalisis dan mengevaluasi proses pemecahan masalah) mahasiswa melakukan refleksi atau evaluasi terhadap penyelidikan mereka dan proses-proses yang mereka gunakan.

Indikator (6) evaluasi (overview), sebelum pembelajaran dengan pembelajaran metode penemuan terbimbing mendapatkan skor $44 \%$, setelah pembelajaran dengan pembelajaran metode penemuan terbimbing mendapatkan skor $74 \%$, dan nilai n-gain 0,54 dengan kategori rendah. Nilai indikator evaluasi rendah disebabkan kurangnya putusan-putusan yang memberikan solusi spesifik dari berbagai sudut pandang. Menurut Duron (2006) bahwa evaluasi adalah sebagai berpikir kritis yang fokus pada nilai dan membuat keputusan berdasarkan informasi.

\section{Peningkatan Keterampilan Berpikir Ktiris dalam Upaya Remediasi Miskonsepsi}

Menurut hasil analisis kuantitatif uji-t, bahwa miskonsepsi dapat menurun secara signifikan ketika diremediasi dengan pembelajaran metode penemuan terbimbing. Akan tetapi ketika diuji korelasi antara peningkatan keterampilan berpikir kritis dengan penurunan hasil remediasi miskonsepsi menghasilkan signifikansi yang rendah. Hal ini menunjukkan bahwa pada penelitian ini pembelajaran metode penemuan terbimbing dapat meningkatkan keterampilan berpikir kritis dan dapat meremidiasi miskonsepsi. Sedangan keterampilan berpikir kritis yang meningkat, tidak membawa dampak yang signifikan terhadap penurunan miskonsepsi.

Menurut teori evaluating claim bahwa keterampilan berpikir kritis akan mengevaluasi konsepkonsep yang salah (Zero, 2011). Menurut hasil analisis kuantitatif di atas bahwa evaluasi claim ini belum berhasil mengevaluasi konsep-konsep yang salah. Hal ini bukan berarti konsep evaluating claim salah, akan tetapi perlu adanya alternatif lain dalam penelitian ini. Kekurangan penelitian ini adalah belum adanya pemaduan antara tes keterampilan berpikir kritis dan tes diagnostis miskonsepsi. Pengembangan perangkat hanya berorientasi pada peningkatan bepikir kritis dan penurunan miskonsepsi. Keterkaitan tes diagnostic 
miskonsepsi seharusnya selaras. Sebagai contoh pengembangan tes yang selaras sebagai berikut; (1) soal diagnostik miskonsepsi yang telah dikembangkan diujikan sebagi uji awal membuktikan adanya miskonsepsi pada mahasiswa atau tidak. (2) Jika terbukti ada, soal itu dicarikan solusi berpikir kritisnya. (3) Selanjutnya solusi keterampilan berpikir kritis itu dikembangkan menjadi soal keterampilan berpikir kritis. (4) Melalui pembelajaran penemuan terbimbing peneliti fokus pada peningkatan keterampilan berpikir kritis terutama keterampilan berpikir kritis solusi permasalahan miskonsepsi.

\section{SIMPULAN}

Berdasarkan hasil penelitian ini dapat disimpulkan bahawa:

1. Implementasi pembelajaran metode penemuan terbimbing materi listrik dinamis dapat meningkatkan keterampilan berpikir kritis mahasiswa.

2. Profil miskonsepsi mahasiswa menurun secara signifikan setelah diremediasi dengan pembelajaran metode penemuan terbimbing

3. Peningkatan keterampilan berpikir kritis berpengaruh terhadap remediasi miskonsepsi mahasiswa materi listrik dinamis, tetapi pengaruhnya tidak signifikan.

Berdasarkan pada hasil penelitian yang telah dilakukan dan adanya beberapa simpulan di atas, disarankan kepada peneliti sejenis untuk:

1. mengembangkan perangkat yang bertujuan untuk meremediasi miskonsepsi melalui berpikir kritis.

2. menganalisis hasil tes diagnostik awal yang diarahkan kepada penyebab terjadinya miskonsepsi tiap (maha)siswa, sehingga memungkinkan untuk mengatasi miskonsepsi dengan berbagai cara menurut penyebabnya tersebut.

\section{DAFTAR PUSTAKA}

Arends, R.,I., .2008. Learn to Teach. Terjemah Helly Prajitnon dan Sri Mulyantini. Yogyakarta: Pustaka belajar.

Berg, E.v.D.. 1991. Miskonsepsi Fisika dan Remidiasi. Salatiga: Universitas Kristen Satya Wacana

Carin, A.A. 1993. Teaching Science Through Discoverry. Canada: MacMillan Publising Company

Collete, A.T. and Chiappetta, 1994. Science Intruction in The Midle and Secondary Schools. Canada : Canada: Merill Publisisng Company.
Duch, J. B. 1995. Problems: A Key Factor in PBL. [Online]. Tersedia http://www.udel.edu/pbl/cte/spr96-phys.html. (15 November 2011)

Duron, R , Limbach, B. and Waugh W. 2006. Critical Thinking Framework For Any Discipline. International Journal of Teaching and Learning in Higher Education. Volume 17, Number 2 1991, pp. 160-166

Ennis, R. H. 1996. Critical Thingking. London : Prentice Hall, Inc.

Fisher, A. 2001. Critical Thinking: An Introduction. New York: Cambrige University Press

Giancoli, D.C. 2009. Physich for Scientists \& Engineers with Modern Physics.New Jersey: Pearson Prentice Hall

Hake, R.R. 1999. Analyzing Change/Gain Scores. Woodlan Hills, Indiana University Journal., CA. 91367 USA

Hasan, S., Diola B, dan Ella L. K. 1999. Misconception and the Certainty of Response Index (CRI). Journal: Physics Education, Vol. 34 No. 5 hal. 294-299

Major, Claire,H.,andPalmer, B.. 2001. Assessing the Effectiveness of Problem Based Learning in Higher Education: Lessons from the Literature. [Online]. Tersedia : www.rapidintellect.com/AE Qweb/mop4spr01.htm (15 November 2011)

Purba, P. and Depari, G., 2008. Penelusuran Miskonsepsi Mahasiswa tentang Konsep dalam Rangkaian Listrik Menggunakan Certainty of Response Index dan Interview. Bandung: FPTK UPI

Saputra, H.A. 2011. Identifikasi Miskonsepsi Siswa pada Konsep Listrik Dinamis Kelas X SMA. Yogyakarta: Universitas Negeri Surakarta

Schafersman, S.,D. 2006. An Intruction of Critical Thinking. $\quad$ www.Freeinquiri.com/critical thinking.html. 31 Oktober 2011

Suparno, P.. 1997. Filsafat Kontruktivisme dalam Pendidikan. Yogyakarta: Kanisius

Thiagarajan, S., Semmel.S., and Semmel, I.M. .1974. Instructional Devalopment for Training Teachers of Exceptional Children A Sourcebook. Indiana: Indiana University.

Universitas Negeri Surabaya, 2011. Buku Pedoman Universitas Negeri Surabaya. Surabaya: Unesa

Woolfolk, Anita. 2009. Educational Psycology Active Learning Edition. Boston: Pearson Education, Inc.

Zero, D. 2011. Thinking Critically and Resolving Misconceptions:

https://sites.google.com/site/dmzeroproject/Home/cr itical-thinking-and-misconceptions: 17 Januari 2012 